\title{
Captain J. D. Proctor
}

Captain John Desmond Proctor, Fleet Captain with British Caledonian Airways, died suddenly in Madrid on Friday, 13 April 1979. Captain Proctor, who was a Fellow of the Institute, served for many years on its Technical Committee and contributed no less than eighteen papers and notes to the Journal (the last of which appears in this number). He had a fertile mind and wrote on many subjects, some of them outside air navigation. Although he was interested in so many facets of navigation, he had a severely practical outlook. To the end he remained an operational pilot.

\section{Captain F. J. Wylie, OBE, RN (ret)}

Captain F. J. Wylie, an Honorary Member, Gold Medallist, Bronze Medallist, Fellow and past President of this Institute, died shortly after Easter, aged 82 .

After a distinguished career in the Royal Navy Captain Wylie devoted a second professional life, which was to last until his death, to the improvement of standards in the application of radar to navigation at sea. As Director of the Radio Advisory Service of the Chamber of Shipping of the U.K. and the Liverpool Steamship Owners' Association, he was responsible from 1948 to 1966 for advising the British shipping industry on radio aids to navigation. Over many years, culminating in his Presidency in $195^{8}$ and 1959, Captain Wylie played a prominent part in the Institute's affairs: he was Chairman of numerous institute working groups, wrote a vast number of papers for the Journal and edited the Institute's handbook The Use of Rador at Sea, a complete revision of which he was able to complete before he died. Captain Wylie's reputation stood high abroad and he was an Honorary Member of both the French and German Institutes of Navigation, and; in 1953 he was awarded the Thurlow Award of the American Institute.

For all his involvement with the technicalities of his task Bill Wylie remained the sailor, and saw things through the eyes of the man on the bridge; it was on his behalf that he sought to apply his many talents. 